\title{
The Fruit Juices Are The Simplest Inhibitors Of Electrochemical Corrosion: Experimental Results
}

\author{
(C) A.A. Sikachina ${ }^{1}$, S.M. Beloglazov ${ }^{2}$ \\ Immanuel Kant Baltic Federal University, \\ 2 University-st., 239000 Kaliningrad-sity, Russian \\ Federation
}

Annotation: in a published article, the anticorrosive properties of inhibitors (inh) - products of fruit and berry raw materials (fruit juice) are investigated on the example of a galvanic cell with irreversible electrodes. The test sample of aluminum Rus-grade “АД1пл" according to «ГОCТ 4784-1997» serves as the cathode, and the roughly processed sample of copper Rusgrade "М00к" according to "ГОСТ 859-2014" serves as an anode (to minimize the polarization of hydrogen evolution). Samples were pre-degreased. A measure of the change in the corrosion process is a function of the time of the magnitude of the current of the galvanic cell, which, in turn, depends on the degree of anodic hydrogen depolarization.

Keywords: aluminum, copper, fruit and berry raw materials, corrosion inhibitor, galvanic cell, adsorption, hydrogen depolarization

\section{Introduction}

Aluminum is the second most commonly used metal after iron - by itself and as part of a wide range of alloys due to the low atomic mass and the negative value of the standard electrode potential of aluminum, which makes it covered with a flexible oxide film.

In an effort to mitigate aluminum corrosion, the main tactic - to separate the metal from corrosive environments.

This can be achieved with the help of corrosion inhibitors. All over the world, recently, the use of chemical inhibitors has been limited due to regulatory acts; plant extracts have become important again as they are an ecological and renewable source for a wide range of necessary inhibitors. Fruit and vegetable products and plant extracts are considered as an incredibly rich source of naturally synthesized chemical compounds that can be extracted using simple and cheap procedures.

It is well-known, that corrosion inhibition occurs by the adsorption of their molecules on the corroding metal surface and the effectiveness of inhibiting the harmful process depends on the mechanical, structural and chemical characteristics of the adsorption layers formed under certain conditions.

Research methods

Selection of a corrosion system

The galvanic cell, prepared for this research, had the following scheme

$$
-\left(\mathrm{S}=15.8 \mathrm{~cm}^{2}\right) \mathrm{Al}|(0.130 \mathrm{~L}, 40 \%) \mathrm{NaOH}|\left(\mathrm{S}=7.8 \mathrm{~cm}^{2}\right) \mathrm{Cu}+
$$

which in the presence of an inhibitor is converted to

\footnotetext{
${ }^{1}$ sikachina@list.ru

2 smbeloglazov@mail.ru
} 
For the description of the experiment, readers will need the following scheme (for example, we give for the galvanic cell (A)):

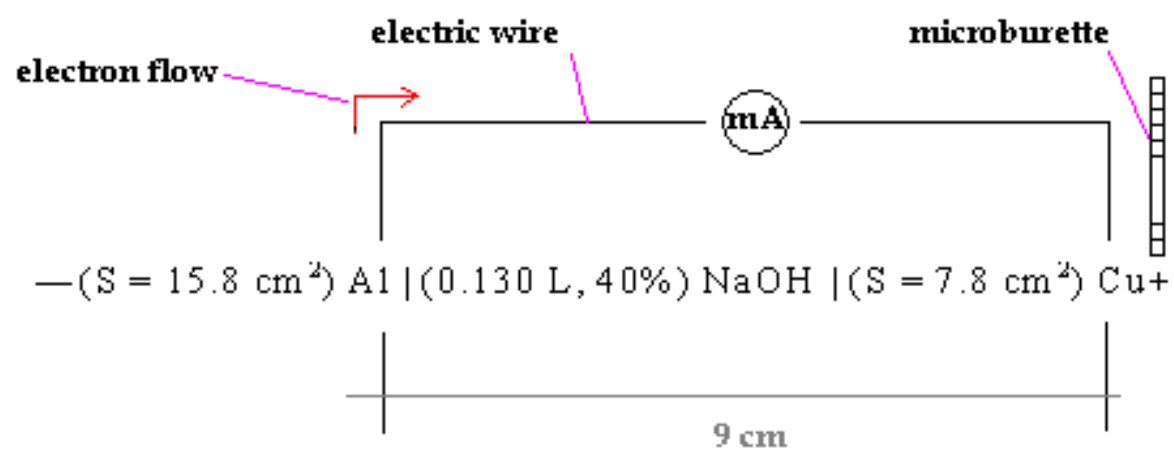

Organic inhibitors of the corrosion process

As inhibitors, freshly squeezed fruit and berry juices ("complex inhibitors") were used, without dilution, taken into the electrolyte in an amount of $10 \mathrm{ml}$ (they become $8.3 \%$ when placed in the electrolyte of the electrochemical cell).

The chemical composition of the tested juices was presented according to the site http://www.intelmeal.ru/.

To calculate the correlation coefficients for individual nutrients of fruit and berry juices, those classes of organic substances were selected that make up the chemical composition, the amount of which is more than $0.01 \mathrm{~g}$ (not counting the ash content and the amount of water, which also revealed the "I- $m$ " - relationship).

It was tested as a corrosion inhibitor $0.07 \mathrm{M} \mathrm{NaBr}$ (this concentration is acquired when a weighted charge is placed in the electrolyte of an electrochemical cell) to more clearly show the difference between an organic inhibitor and an inorganic inhibitor.

The technology of our experiment

The protective effect of the inhibitor from corrosion

\section{Current strength}

Current of the both galvanic cell $\mathbf{A}$ and $\mathbf{B}$ was measured every minute (stopwatch) with an "ABO-5M"- instrument.

At the initial circuit of the circuit, the moment of which the immersion of an aluminum sample of a prescribed area was considered to be in the galvanic cell solution, the current of a point of 0 min was recorded, which was very different from the values of subsequent minutes, because a side element

$$
-\left(\mathrm{S}=15.8 \mathrm{~cm}^{2}\right)(\mathrm{Al}), \mathrm{Al}_{2} \mathrm{O}_{3}|(0.130 \mathrm{~L}, 40 \%) \mathrm{NaOH}|\left(\mathrm{S}=7.8 \mathrm{~cm}^{2}\right) \mathrm{Cu}+
$$

or

- $\left(\mathrm{S}=15.8 \mathrm{~cm}^{2}\right)(\mathrm{Al}), \mathrm{Al}_{2} \mathrm{O}_{3} \mid(0.130 \mathrm{~L}, 40 \%) \mathrm{NaOH},(0.010 \mathrm{~L}, 100 \%)$ inh $\mid\left(\mathrm{S}=7.8 \mathrm{~cm}^{2}\right) \mathrm{Cu}+$ 
worked at that point, characterized by the presence of an oxide film on the cathode. With a high concentration of alkali by the action of the interfering element $-\mathrm{Al}\left|\mathrm{H}_{2} \mathrm{O}\right| \mathrm{Cu}+$ or $-\mathrm{Al} \mid \mathrm{H}_{2} \mathrm{O}$, inh $\mid \mathrm{Cu}+$ can be neglected.

The time of the experiment with each inhibitory additive was different. The criterion for the end of the experience cycle was the equality of the values of the current for 3 minutes.

\section{Hydrogen depolarization}

To analyze the degree of polarization at the anode, we chose the volume of depolarized hydrogen $\left(\mathrm{H}_{2} \mathrm{O}+\mathrm{e} \rightarrow \mathrm{H}_{\mathrm{ads}}+\mathrm{OH}^{-}\right)$, which was measured using with 0.01 ml-microburette. Organic inhibitors acted on the overpotential of hydrogen evolution on copper, being chemically-adsorbed on copper. The $\mathrm{H}_{2}$-gas level was measured according to a serial number of a minute called $\boldsymbol{n}$ was recorded when $0.02 \mathrm{ml}$ of gas was released.

\section{Correlation coefficients}

The values of the Pearson correlation coefficients were compiled by MS Excel 2007; they reflected the relation between the current strength and the chemical composition component (i.e. "I- $m$ "). The current was applied for $n=1 \ldots 3$.

\section{Results and interpretations}

\section{Current change, $\mathrm{mA}$}

It is presented in Figure 1. "Control" is implied as a reference.
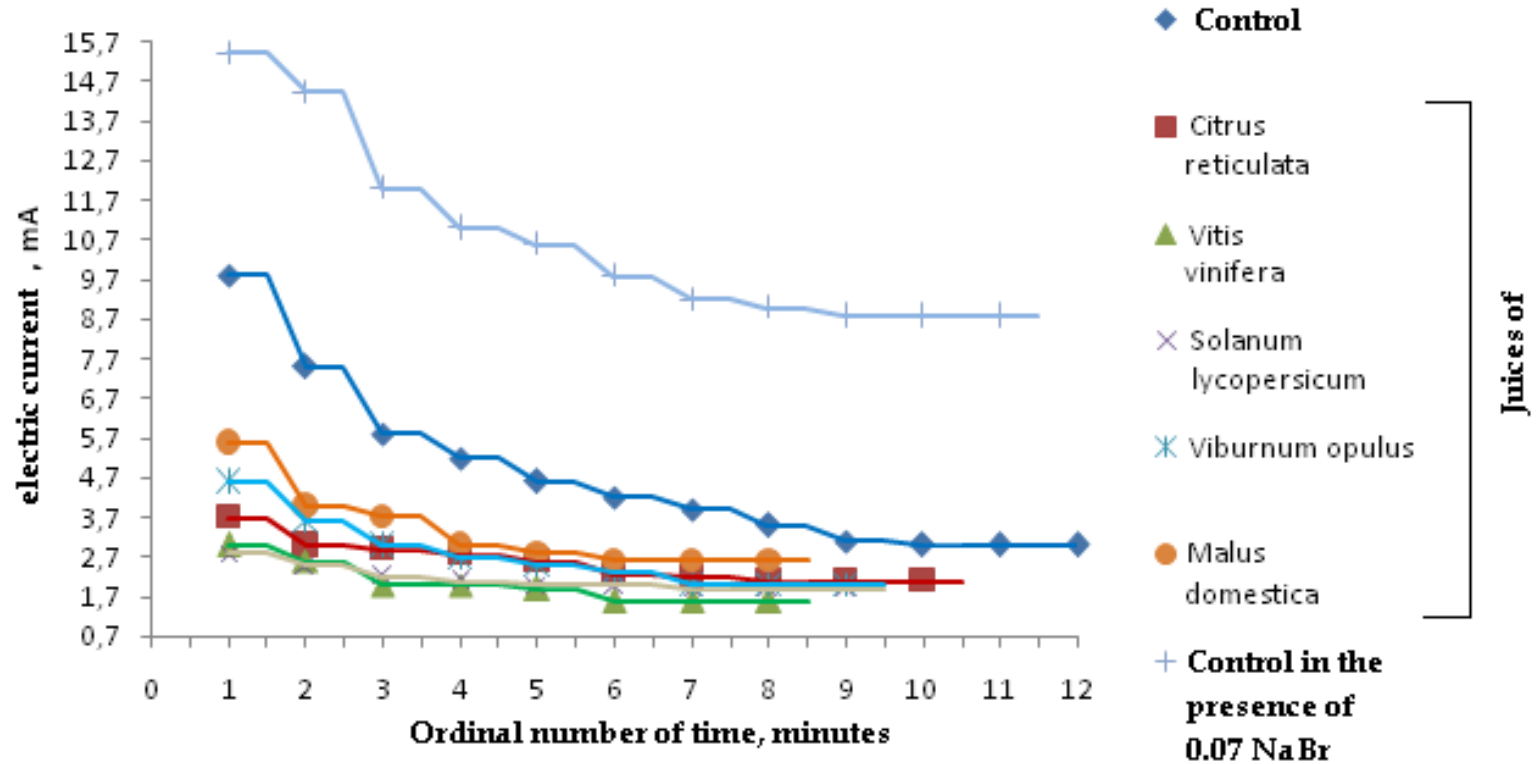

Fig. 1. The results of the inhibitory effect of fruit juice

The best inhibitors are those, that prevent for run of electron density from water-molecules on anode surface and reduce the recombination of $\mathrm{H}$ atoms with that by the reaction $2 \mathrm{H}_{\mathrm{ads}} \rightarrow \mathrm{H}_{2}$. All inhibitors reduce the magnitude of the current, since the inhibiting composition is hydrated by water molecules, on the graph it looks like the general nature of the decrease in current as a function of time. Moreover, the decrease in current in the presence of both "tangerine" and "tomato" juice is the smoothest. 
Further, it is the chemical composition of juices that determines the best inhibitor. It is "grape" juice. The worst inhibitor is "apple" juice.

The contribution of the chemical composition in the current

Shown as correlation coefficients in fractions of a unit (Table 1)

Tab. 1. The contribution of the most numerous components of the chemical composition of the product processing fruit and berry raw materials in the magnitude of the decrease in the current strength of a galvanic element

\begin{tabular}{|l|c|l|l|}
\hline \multirow{2}{*}{$\begin{array}{l}\text { Organic compounds of } \\
\text { our inhibitor for mass }\end{array}$} & \multicolumn{3}{|c|}{$\begin{array}{l}\text { Current } \boldsymbol{I} \text { at ordinal } \\
\text { number of minutes } \boldsymbol{n}\end{array}$} \\
\cline { 2 - 4 } $\boldsymbol{m}$ & \multicolumn{3}{|c|}{$\begin{array}{c}|c| \\
\text { "I-m" - correlation } \\
\text { coefficients }\end{array}$} \\
\cline { 2 - 4 } & +0.81 & $+0,65$ & $+0,62$ \\
\hline Carbohydrates & $+0,31$ & $-0,02$ & $-0,09$ \\
\hline $\begin{array}{l}\text { Of which monoses, } \\
\text { disaccharides }\end{array}$ & $-0,03$ & $+0,13$ & $+0,31$ \\
\hline Of which sucrose & $+0,11$ & $-0,27$ & $-0,41$ \\
\hline Of which glucose & $+0,39$ & $+0,04$ & $-0,06$ \\
\hline Of which fructose & $-0,10$ & $-0,35$ & $-0,63$ \\
\hline Of which dietary fiber & $+0,47$ & $+0,43$ & $+0,22$ \\
\hline Fat & $-0,67$ & $-0,67$ & $-0,54$ \\
\hline Squirrels & $-0,90$ & $-0,75$ & $-0,67$ \\
\hline Water & $+0,59$ & $+0,49$ & $+0,49$ \\
\hline Ash-content & & & \\
\hline
\end{tabular}

The greatest number of power "+ I- $m$ " - correlatios is observed in the first minute of the experiments, then the bond power drops. This is caused by less polarization of the anode (by less electron density). The growth of the correlation coefficients over time is achieved in sucrose, which is a non-reducing disaccharide and does not carry a negative center in its structure.

The degree of hydrogen depolarization of the copper anode

Comparison takes place on the example of the best inhibitor and worst inhibitor.

Tab. 2. The results of gas-separation due to depolarization of anode, as well as the current strength, developed by the secondary - (Al), $\mathrm{Al}_{2} \mathrm{O}_{3}|\mathrm{NaOH}| \mathrm{Cu}+$

\begin{tabular}{|c|c|c|c|}
\hline $\begin{array}{c}\text { The inhibitor ( } \\
\text { "fruit juice") or } \\
\text { control }\end{array}$ & $\begin{array}{c}\text { The ordinal number of } \\
\text { minute, when the release of } \\
\mathbf{0 . 0 2} \mathbf{~ m l ~ o f ~} \mathbf{H}_{2} \text { is registered }\end{array}$ & $\begin{array}{c}\text { The recorded } \\
\text { allocation of } \mathbf{H}_{2} \\
\text { during the }\end{array}$ & $\begin{array}{c}I \text {-value at } \mathbf{0} \\
\text { (zero) } \\
\text { minute }\end{array}$ \\
\hline
\end{tabular}

\footnotetext{
${ }^{3}$ Due to the oscillation of the galvanometer needle due to the rapid dissolution of the oxide film, the values are rounded
} 


\begin{tabular}{|l|c|c|c|}
\hline & & experiment, ml & \\
\hline Control & $<1$ & 0.27 & 20 \\
\hline Citrus reticulata & 3 & 0.19 & 13 \\
\hline $\begin{array}{l}\text { Solanum } \\
\text { lycopersicum }\end{array}$ & 4 & 0.04 & 13 \\
\hline $\begin{array}{l}\text { Viburnum } \\
\text { opulus }\end{array}$ & 5 & 0.05 & 11.5 \\
\hline Vítis vinífera & 5 & 0.08 & 10 \\
\hline Malus domestica & 6 & 0.06 & 9 \\
\hline $\begin{array}{l}\text { Control in } \\
\text { presence 0.07 M } \\
\text { NaBr }\end{array}$ & 6 & 0.20 & 18 \\
\hline
\end{tabular}

$\mathbf{H}_{2}$ - gas emissions are higher in "grape juice". This is due to a greater change in the properties of the electrolyte. There is a competition between the speeds of the following both processes $\mathrm{H}_{2} \mathrm{O}+\mathrm{e}^{-} \rightarrow \mathrm{H}_{\mathrm{ads}}+2 \mathrm{OH}^{-}$(1) and $2 \mathrm{H}_{\mathrm{ads}} \rightarrow \mathrm{H}_{2}$ (2). In the presence of "grape juice" in the electrolyte, the process (1) proceeds more slowly than the process (2). In the presence of "apple juice" in the electrolyte, the process (1) proceeds faster than the process (2). This is due to colloidal processes (adhesion, a certain charge on the surface of copper, etc.). A high current in the presence of sodium bromide (which is also a reducing agent: $\mathrm{Br}_{2}+2 \mathrm{e}^{-} \rightarrow 2 \mathrm{Br}^{-}$, and the electrochemical potential is $+1.06 \mathrm{~V}$ ) is explained by the dissociation of the electrolyte, i.e. by an increase in the apparent concentration of particles by about 2 times.

\section{Conclusion}

Obviously, $8.3 \%$ solutions of fruit juices (which they become when an electrochemical cell is placed in an electrolyte), on average, halve the amperage developed by a galvanic cell (for example, the worst inhibitor) and 1.5 times the volume of depolarized hydrogen. From the analysis of the correlation coefficients, it was found that the manifestation of inhibiting properties is influenced by the mass fraction of carbohydrates, and the most decisive influence is the mass fraction of sucrose. Such data characterize fruit and berry juices as inhibitors of medium strength and allow us to recommend them for more in-depth study and implementation, if not for the enormous cost of such products of processing fruit and berry raw materials in Russia.

\section{Bibliography}

1. Deepa Prabhu and Padmalatha Rao, "Garcinia indica as an Environmentally Safe Corrosion Inhibitor for Aluminium in $0.5 \mathrm{M}$ Phosphoric Acid," International Journal of Corrosion, vol. 2013, Article ID 945143, 11 pages, 2013. https://doi.org/10.1155/2013/945143.

2. P. Arora, S. Kumar, M. K. Sharma, and S. P. Mathur, "Corrosion Inhibition of Aluminium by Capparis deciduas in Acidic Media," E-Journal of Chemistry, vol. 4, no. 4, pp. 450-456, 2007. https://doi.org/10.1155/2007/487820. 